\title{
Genetic Behavior for Reverse Thermo-Sensitive Genic Male Sterility (RTGMS) through Segregating Generations of some Rice Genotypes in Egypt
}

\author{
S. A. Dora*, M. E. El-Dinary**, M. I. Abo Yousef*** and M. E. Selim*** \\ *Department of Genetics, Faculty of Agriculture, Kafrelsheikh University, ** \\ Department of Genetics, Faculty of Agriculture, Tanta University and *** Rice \\ Research and Training Center, Agriculture Research Centre, Cairo, Egypt.
}

$\mathbf{F}$ IFTY populations selected from F2 for two crosses i.e. cross I (M.J. $5460 \mathrm{~S} \times$ Sakha 106) and cross II (M.J. $5460 \mathrm{~S} \times$ GZ7768) were planted as F3 generation in 2013 season and twenty populations were selected from F3 and planted as F4 generation in 2014 season. The selected populations were studied for reverse thermo-sensitive genic male sterility (rTGMS) trait, some growth and yield traits were measured. The F4 populations means were lower than the means of F3 populations only in the days to heading trait while, F4 means were higher than F3 means in the other studied traits. These data indicated the improvement for most studied traits by selection. High heritability was estimated in broad sense for all growth and yield traits in both crosses as F3 and F4generations. Heritability in narrow sense ranged between $35.79 \%$ for number of tillers trait in cross I as F3 generation to $74.95 \%$ for days to heading trait in cross I as F3 generation. The highest genetic advance from selection as percentage of mean $(\Delta \mathrm{g} \%)$ was 63.72 for yield per plant trait in cross II in F4 generation. Molecular studies indicated that, the RM222 as specific SSR primer revealed the presence of one specific band with molecular size of (200 bp) with M.J 5460S line as reverse thermo-sensitive genic male sterile line which indicated that, this band may be related to reverse thermo-sensitive genic male sterility gene. It could be concluded that RM222 as specific SSR primer could be used to identify the rtms 1 gene in reverse thermo-sensitive genic male sterile lines, which could be used in japonica hybrid rice seed production under Egyptian conditions.

Keywords: Rice, Genotypes, Sterility, Genetic behavior.

\section{Introduction}

Rice (Oryza sativa L.) is being cultivated in around 113 countries of the world. About half of the world's population depends on rice for their survival (Singh et al., 2015). Commercial exploitation of hybrid vigor is one of the most important applications of genetics in agriculture. It has not only contributed to food security, but has also benefited the environment (Duvick 1999). Hybrid rice based on cytoplasmic male sterility (CMS) increases grain yield by more than $20 \%$ relative to improved inbred rice varieties (Yuan and Virmani, 1994).

The discovery and successful utilization of environmental genic male sterility (EGMS) led to develop new promising hybrids of two lines system in hybrid rice breeding program. Compared with the three-line system, the two line system has many advantages for hybrid rice production such as no need to use maintainer line for seed parent multiplication, thus making seed production simpler and more cost-effective. EGMS trait is governed by major genes could be transfer to any genetic background and no need to use restorer genes in the male parents of two line hybrids. Finally, this system is ideal for developing indica / japonica hybrids because most japonica lines do not possess restorer genes (Virmani et al., 2003).

The EGMS is composed of two major types, photo-sensitive genic male sterility (PGMS), which is responsive to variations in day length, and thermo-sensitive genic male sterility 
(TGMS), which is caused by temperature. One such thermo sensitive genic male sterile TGMS line, J207S, is completely sterile when the temperature is lower than $31^{\circ} \mathrm{C}$, but fertile when the temperature is higher than $31^{\circ} \mathrm{C}$, and thus it is named as the reverse-thermo sensitive genic male sterile (rTGMS) line (Jia et al., 2001). Heritability and genetic advance are important selection parameters. Heritability estimates along with genetic advance are normally more helpful in predicting the gain under selection than heritability estimates alone (Johnson et al., 1955 and Parmeshwar et al., 2015). Molecular studies is concerning on selecting populations which can be used as the new reverse-thermo sensitive genic male sterile (rTGMS) lines to produce Japonica hybrids under Egyptian condition by used one specific SSR primer RM222 according to Jia et al. (2001).

Our goals in this investigation summarized in selecting emphasized on high of yielding populations with improved desirable traits. Selecting populations which could be used as female lines (rTGMS) and other one could be used as male lines to produce japonica hybrid rice seed production with high productivity under Egyptian condition.

\section{Material and Methods}

The experimental work of the present investigation was carried out at the farm of Rice Research and Training Center (RRTC), Sakha, Kafr El-Sheikh, Egypt and laboratories of Genetics Department, Faculty of Agriculture -Tanta University during the two successive growing seasons 2013 and 2014. Fifty populations selected from $\mathrm{F}_{2}$ based on reverse Thermo-sensitive Genic Male Sterility (rTGMS) phenotype with selection index $(5 \%)$ for studied characters were planted as $\mathrm{F}_{3}$ generation in 2013 season and twenty populations were selected from $\mathrm{F}_{3}$ were planted as $\mathrm{F}_{4}$ generation in 2014 season. The experimental were arranged in Randomized Complete Block Design (RCBD) with five replications for tow crosses [M.J. $5460 \mathrm{~S}$ $\times$ Sakha 106 (cross I)], and [M.J. $5460 \mathrm{~S} \times$ GZ7768 (cross II)]. The two crosses produced from hybridization between one reverseThermo Sensitive Genic Male Sterile (rTGMS) line, M.J $5460 \mathrm{~S}$ as a female line with one
Egyptian cultivar, Sakha106 and one new promising line GZ.7768 as male lines in cross I and cross II, respectively. We were selected three populations which around of general mean values.

The studied traits were days to heading (day), no. of tillers plant ${ }^{-1}$, flag leaf area $\left(\mathrm{cm}^{2}\right)$, seed set $(\%)$ and yield plant $^{-1}(\mathrm{~g})$. Cultural practices were applied as recorded by RRTC (2013). The data were analyzed by Kearsey Model of Kearsey and Pooni (1996); through estimation of the variances between and within populations for $\mathrm{F}_{3}$ and $\mathrm{F}_{4}$ generation and estimation of heritability according to Johnson et al. (1955) and Allard (1964) and genetic advance in percentage of mean, GA (\%) according to Comstock and Robinson (1952). Molecular studies were applied for DNA which was isolated according to CTAB method Murray and Thompson (1988). The selected genotypes used in this study were subjected to DNA polymorphism screening and assessment using RM222 as specific SSR primer for reverse thermo-sensitive genic male sterility trait according to Jia et al. (2001).

\section{Results and Discussion}

Mean performance values and standard error for the parents and two japonica hybrid combinations as $\mathrm{F}_{3}$ and $\mathrm{F}_{4}$ generations during 2013 and 2014 seasons under investigation for studied traits are presented in Table $1 \mathrm{a} \& \mathrm{~b}$. The mean performance values for $\mathrm{P}_{1}$ [M.J. $5460 \mathrm{~S}$ ] as female line and the other two parents [Sakha106 and GZ.7768] as male lines, showed differences among the three parents for all studied traits. The $\mathrm{F}_{4}$ population's means were 97.12 and 97.89 in cross I and cross II respectively which were lower than the means of $F_{3}$ population's means 91.33 and 91.23 in cross I and II respectively for days to heading trait. On the other hand, the $\mathrm{F}_{4}$ population's means were higher than the means of $\mathrm{F}_{3}$ populations in the two crosses for no. of tiller plant ${ }^{-1}$, flag leaf area $\left(\mathrm{cm}^{2}\right)$, seed set $\%$ and yield plant ${ }^{-1}$ which indicated the improvement for most studied traits under selection. Especially the improvement in yield plant ${ }^{-1}$ trait for the $\mathrm{F}_{4}$ population's means were 66.46 and 70.09 in the cross I and cross II respectively which were higher than the $\mathrm{F}_{3}$ population's means which were 63.56 and 65.91 in the cross I and cross II respectively. 
TABLE 1a. Mean performance and standard error for the studied traits for two hybrid combinations as $F_{3}$ and $F_{4}$ generations with their parents during 2013 and 2014 seasons.

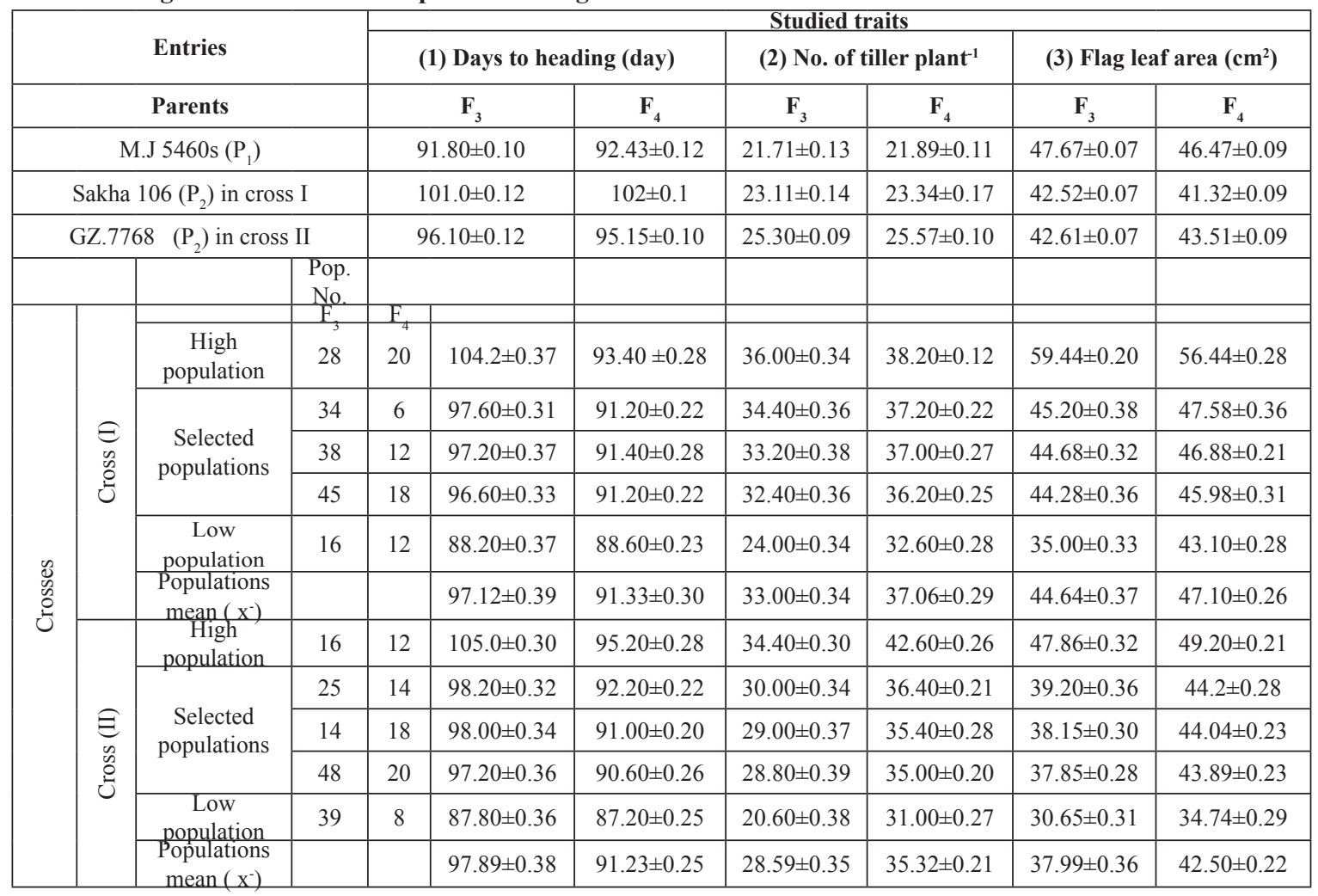

TABLE 1b. Mean performance and standard error for the studied traits for two hybrid combinations as $F_{3}$ and $F_{4}$ generations with their parents during 2013 and 2014 seasons.

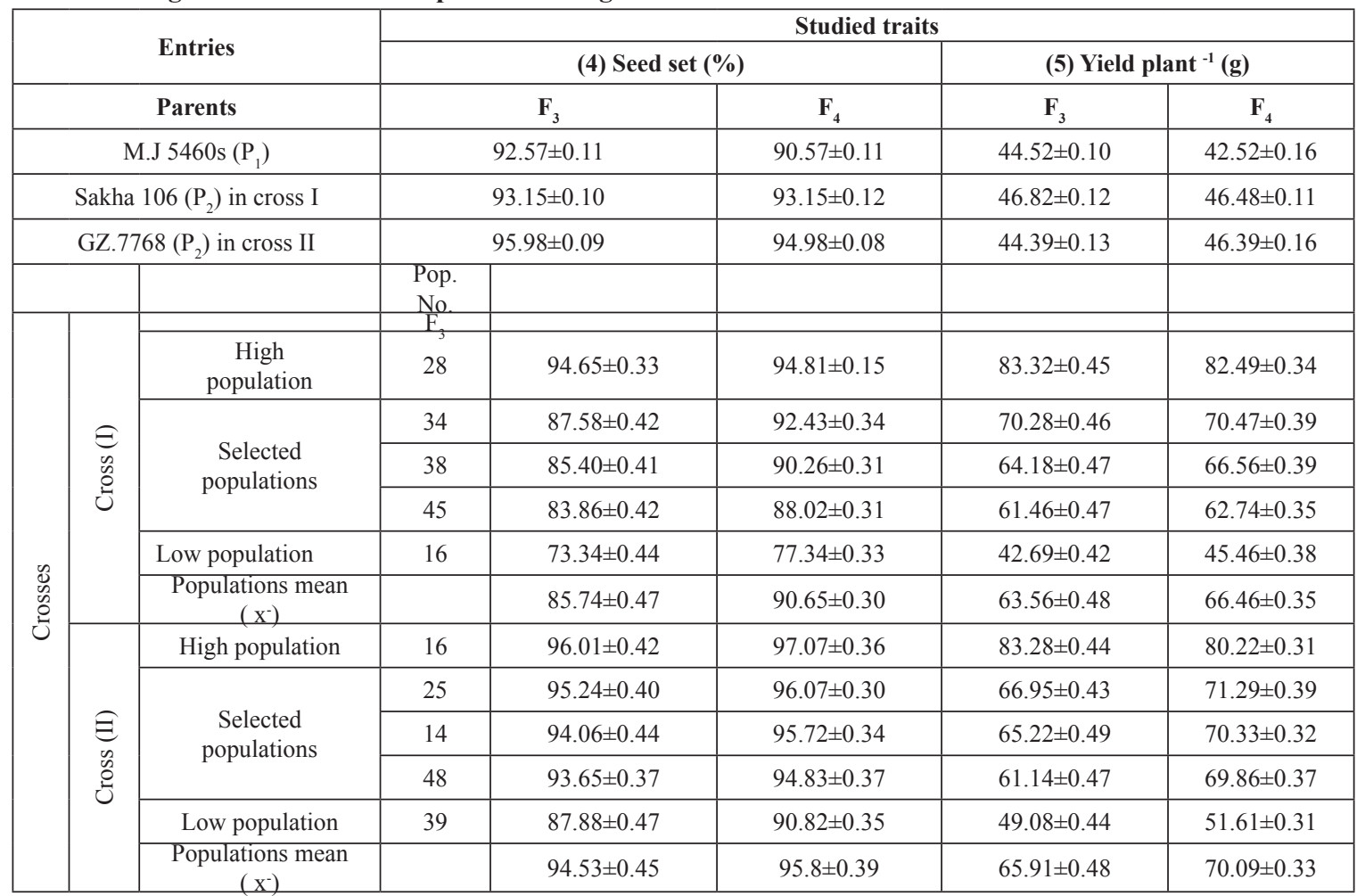

Cross I (M.J. 5460S $\times$ Sakha 106) and cross II (M.J. 5460S $\times$ GZ7768). 
Genetic parameters involved, additive variance, dominance variance, environment variance and heritability estimates in both broad and narrow senses of two japonica hybrid combinations as $\mathrm{F}_{3}$ and $\mathrm{F}_{4}$ generations during 2013 and 2014 seasons under investigation for studied traits are presented in Table $2 \mathrm{a} \& \mathrm{~b}$. Additive variance appear in days to heading and yield plant $^{-1}$ for cross $\mathrm{I}$ as $\mathrm{F}_{3}$ generation while, dominance variance appear in other studied traits for each cross I and II. Heritability estimates in broad sense $\left(\mathrm{h}_{2} \mathrm{~b} \%\right)$ in $\mathrm{F}_{3}$ and $\mathrm{F}_{4}$ were high in all studied traits with values ranged from $94.50 \%$ of the cross $\mathrm{I}$ in number of tillers plant ${ }^{-1}$ trait as $\mathrm{F}_{3}$ generation to $99.70 \%$ of cross II in yield plant ${ }^{-1}$ trait as $\mathrm{F}_{4}$ generation.

These results are in agreement with the results obtained by Patel et al. (2012) who recorded higher heritability for days to $50 \%$ flowering, total tillers and yield plant-1. Sedeek et al. (2009) found high heritability in broad sense for flag leaf area $(\mathrm{cm} 2)$. Heritability estimates in broad sense (h2b \%) were high in the two studied crosses in both generations for seed set (\%), these results were in agreement with the results obtained by El Shamey (2016). These results indicated that, the genotypic variances played the major part of phenotypic variances for all studied traits. Heritability estimates in narrow sense (h2n \%) in $\mathrm{F} 3$ and F4 ranged between moderate to high with values ranged from $35.79 \%$ in the cross I for no. of tillers plant-1 trait as F3 generation to 74.95 $\%$ for the cross I in days to heading trait. These results were in agreement with the results obtained by Ahmadikhah (2010) who found that, days to heading showed high narrow sense heritability $(60.7 \%)$. The genetic advance from selection $(\Delta \mathrm{g})$ and the expected genetic advance from selection as percentage from each of F3 and F4 mean $(\Delta \mathrm{g}$ $\%)$ of tow japonica hybrid combinations during 2013 and 2014 seasons under investigation for the studied traits are presented in Table 3.

TABLE 2a. Genetic components and heritability in broad and narrow senses for the studied traits of the tow japonica hybrid combinations as $F_{3}$ and $F_{4}$ generations during 2013 and 2014 seasons

\begin{tabular}{|c|c|c|c|c|c|c|c|}
\hline \multirow{2}{*}{ Studied traits } & \multirow{2}{*}{ Cross-es } & \multicolumn{2}{|c|}{$\sigma^{2} \mathbf{A}$} & \multicolumn{2}{|c|}{$\sigma^{2} D$} & \multicolumn{2}{|c|}{$\boldsymbol{\sigma}^{2} \mathbf{E}$} \\
\hline & & $\left(F_{3}\right)$ & $\left(F_{4}\right)$ & $\left(F_{3}\right)$ & $\left(F_{4}\right)$ & $\left(F_{3}\right)$ & $\left(F_{4}\right)$ \\
\hline \multirow{2}{*}{$\begin{array}{l}\text { Days to heading } \\
\text { (day) }\end{array}$} & I & 35.75 & 2.43 & 10.93 & 2.65 & 1.02 & 0.03 \\
\hline & II & 28.12 & 5.84 & 32.93 & 6.24 & 3.09 & 0.05 \\
\hline \multirow{2}{*}{ No. of tiller plant ${ }^{-1}$} & $\mathrm{I}$ & 38.33 & 5.30 & 62.89 & 8.89 & 5.90 & 0.45 \\
\hline & II & 41.70 & 10.22 & 45.92 & 11.49 & 4.31 & 0.16 \\
\hline \multirow{2}{*}{$\begin{array}{c}\text { Flag leaf area } \\
\left(\mathrm{cm}^{2}\right)\end{array}$} & I & 83.58 & 31.55 & 103.82 & 39.31 & 9.73 & 0.97 \\
\hline & II & 26.20 & 24.82 & 27.89 & 27.72 & 2.61 & 0.36 \\
\hline \multirow{2}{*}{$\begin{array}{l}\text { Seed set } \\
(\%)\end{array}$} & $\mathrm{I}$ & 305.40 & 190.93 & 352.83 & 253.53 & 33.08 & 7.82 \\
\hline & II & 114.07 & 115.41 & 118.94 & 161.53 & 11.15 & 5.76 \\
\hline \multirow{2}{*}{ Yield plant $^{-1}(\mathrm{~g})$} & I & 415.70 & 167.66 & 387.94 & 178.66 & 36.37 & 1.38 \\
\hline & II & 183.28 & 128.10 & 222.57 & 134.52 & 20.87 & 0.80 \\
\hline
\end{tabular}

Cross: I (M.J. $5460 \mathrm{~S} \times$ Sakha 106) and cross II (M.J. $5460 \mathrm{~S} \times$ GZ7768)

TABLE 2b. Genetic components and heritability in broad and narrow senses for the studied traits of the tow japonica hybrid combinations as $F_{3}$ and $F_{4}$ generations during 2013 and 2014 seasons

\begin{tabular}{|c|c|c|c|c|c|}
\hline \multirow{3}{*}{ Studied traits } & \multirow{3}{*}{ Crosses } & \multicolumn{4}{|c|}{ Heritability } \\
\hline & & \multicolumn{2}{|c|}{$h_{2}(b) \%$} & \multicolumn{2}{|c|}{$h_{2}(n) \%$} \\
\hline & & $\left(\mathrm{F}_{3}\right)$ & $\left(\mathrm{F}_{4}\right)$ & $\left(\mathrm{F}_{3}\right)$ & $\left(F_{4}\right)$ \\
\hline \multirow{2}{*}{$\begin{array}{l}\text { Days to } \\
\text { heading } \\
\text { (day) }\end{array}$} & I & 97.85 & 99.47 & 74.95 & 47.61 \\
\hline & II & 95.19 & 99.58 & 43.84 & 48.12 \\
\hline \multirow{2}{*}{$\begin{array}{l}\text { No. of tiller } \\
\text { plant }^{-1}\end{array}$} & I & 94.50 & 96.93 & 35.79 & 36.20 \\
\hline & II & 95.32 & 99.27 & 45.36 & 46.73 \\
\hline \multirow{2}{*}{$\begin{array}{l}\text { Flag leaf area } \\
\qquad\left(\mathrm{cm}^{2}\right)\end{array}$} & I & 95.06 & 98.65 & 42.40 & 43.92 \\
\hline & II & 95.39 & 99.31 & 46.20 & 46.91 \\
\hline \multirow{2}{*}{$\begin{array}{c}\text { Seed set } \\
(\%)\end{array}$} & I & 95.22 & 98.27 & 44.18 & 42.21 \\
\hline & II & 95.45 & 97.96 & 46.72 & 40.83 \\
\hline \multirow{2}{*}{$\begin{array}{l}\text { Yield plant }^{-1} \\
(\mathrm{~g})\end{array}$} & I & 95.67 & 99.60 & 49.49 & 48.22 \\
\hline & II & 95.11 & 99.70 & 42.95 & 48.63 \\
\hline
\end{tabular}

Cross: I (M.J. $5460 \mathrm{~S} \times$ Sakha 106) and cross II (M.J. $5460 \mathrm{~S} \times$ GZ7768) 
TABLE 3. The expected genetic advance $(\Delta \mathrm{g})$ and the expected genetic advance $(\%)$ as percentage of $F_{3}$ and $F_{4}$ generations means for studied traits of tow japonica hybrid combinations during 2013 and 2014 seasons.

\begin{tabular}{|c|c|c|c|c|c|}
\hline \multirow{3}{*}{ Characters } & \multirow{3}{*}{ Crosses } & \multicolumn{4}{|c|}{ Genetic advance } \\
\hline & & \multicolumn{2}{|c|}{$\Delta \mathrm{g}$} & \multicolumn{2}{|c|}{$\Delta \mathrm{g} \%$} \\
\hline & & $\mathbf{F}_{3}$ & $\mathbf{F}_{4}$ & $\mathbf{F}_{3}$ & $\mathbf{F}_{4}$ \\
\hline \multirow[t]{2}{*}{ Days to heading (day) } & $\mathrm{I}$ & 13.92 & 4.63 & 14.33 & 5.07 \\
\hline & II & 15.70 & 7.15 & 16.04 & 7.83 \\
\hline \multirow[t]{2}{*}{ No. of tiller plant ${ }^{-1}$ (No.) } & I & 20.15 & 7.64 & 61.04 & 20.61 \\
\hline & II & 18.83 & 9.56 & 65.84 & 27.07 \\
\hline \multirow[t]{2}{*}{ Flag leaf area $\left(\mathrm{cm}^{2}\right)$} & I & 27.50 & 17.22 & 61.59 & 36.57 \\
\hline & II & 14.80 & 14.88 & 38.95 & 35.01 \\
\hline \multirow[t]{2}{*}{ Seed set $(\%)$} & I & 51.57 & 43.05 & 67.89 & 55.51 \\
\hline & II & 30.72 & 33.93 & 36.23 & 39.91 \\
\hline \multirow[t]{2}{*}{ Yield plant $^{-1}$} & $\mathrm{I}$ & 47.48 & 38.26 & 99.75 & 63.72 \\
\hline & II & 40.47 & 30.72 & 61.41 & 36.23 \\
\hline
\end{tabular}

The genetic advance as percentage of mean was categorized as high $(>20 \%)$, moderate $(10-20 \%)$ and low $(<10 \%)$ as suggested by Parmeshwar et al. (2015). The expected genetic advance from selection $(\Delta \mathrm{g})$ ranged from 4.63 for days to heading trait of the cross $\mathrm{I}$ in $\mathrm{F}_{4}$ generation to 51.57 for seed set $(\%)$ trait in the cross I as $\mathrm{F}_{3}$ generation. While, the estimates of predicted genetic advance from selection as percentage of each of $\mathrm{F}_{3}$ and $\mathrm{F}_{4}$ means $(\Delta \mathrm{g} \%)$ ranged from 5.07 $\%$ for days to heading trait of the cross $\mathrm{I}$ as $\mathrm{F}_{4}$ generation to $99.75 \%$ for yield plant ${ }^{-1}$ trait in the cross I were estimated from $\mathrm{F}_{3}$ generation. From forgoing results indicating that expected genetic advance from selection $(\Delta \mathrm{g})$ and predicted genetic advance from selection as percentage means $(\Delta \mathrm{g}$ $\%$ ) in $\mathrm{F}_{3}$ generation more than $\mathrm{F}_{4}$ generation which refers to variation in $\mathrm{F}_{3}$ more than in $\mathrm{F}_{4}$. The traits which showed high heritability coupled with moderate or high genetic advance can be improved by intermitting superior genotypes of segregating populations to developed new recombination through selection breeding program (Samadhia 2005). Similar findings were also supported by Jayashudha \& Sharma (2010) and Karuppaiyan et al. (2013) who found that, high heritability coupled with high genetic advance for grain yield per plant trait may be effective for selection in early segregating generations to improve this trait.

Ten of reverse Thermo-sensitive Genic Male Sterile (rTGMS) populations were selected under field experiment from both crosses, I and II which include the best populations were selected on the basis of growth and yield traits under field selection experiment with numbers 6 , 12 and 18 of cross I (Fig.1) and 14, 18 and 20 of cross II (Fig.2) from twenty populations from $\mathrm{F}_{4}$ generation. We should complete the selection program on populations 6,12 and 18 of cross I for using it as new reverse-thermo sensitive genic male sterile lines (female lines) and populations 14,18 and 20 of cross II which will be used as (male lines) to produce high yield Japonica hybrids under Egyptian conditions. Molecular studies were used to support field experiments to select the best populations which could be used as female and male lines to use it to produce high productivity Japonica hybrid rice. Data presented in Fig. 1 demonstrated that the application of RM222 as SSR primer revealed the presence of only one DNA band with molecular size of $200 \mathrm{bp}$.

This band was found in the rTGMS line (M.J 5460 S) as female line and all used populations, except population no. 2 which did not exhibit this band. Also, this band was completely absent in Sakha 106 line, which used as a male line in this experiment. It could be concluded that this DNA band (200 bp) plays an important role in the appearance of rTGMS activity in M.J $5460 \mathrm{~S}$ line and the nine lines which produced this band as a result of using specific SSR marker (RM222). Also, this band may be produced as a result of rTGMS gene(s) expression in the M.J 5460 S line and the nine related populations, which showed this band.

From the molecular genetics point of view this band should be isolated, cloned and sequenced in further study to determine its relationship with the gene(s) which are responsible for rTGMS activity. Data shown in Fig. 2 demonstrated that using SSR primer RM222 revealed the presence of the same band (200 bp) found in Fig. 1 with M.J 5460S line as reverse thermo-sensitive genic male sterile line. This band was absent in GZ7768 which was used as a male line in cross II. This specific 
band (200 bp) was present in four populations with numbers 1, 3, 6 and 8 from ten selected $\mathrm{F}_{4}$ populations and absent in six populations with numbers $2,4,5,7,9$ and 10 which include the best populations selected on the basis of growth and yield traits under field selection experiment with numbers 14, 18 and 20 from twenty $F_{4}$ populations. On the other hand, the nine populations in Fig. 1 and four populations in Fig. 2 which expressed the specific DNA band of $200 \mathrm{bp}$ should be selected and examined for rTGMS activity as a result for the presence of this specific band in their genomes.
This result indicated that analysis of the DNA banding patterns using RM222 marker, revealed a clear difference between the reverse thermo-sensitive genic male sterile (rTGMS) line and the other fertile parents which were used in this study. Similar results were obtained by Jia et al. (2001) who found that, the primer RM222 could be used to identify the $\mathrm{rtms}_{1}$ gene in reverse thermo-sensitive genic male sterile lines, which could be used in japonica hybrid rice seed production.

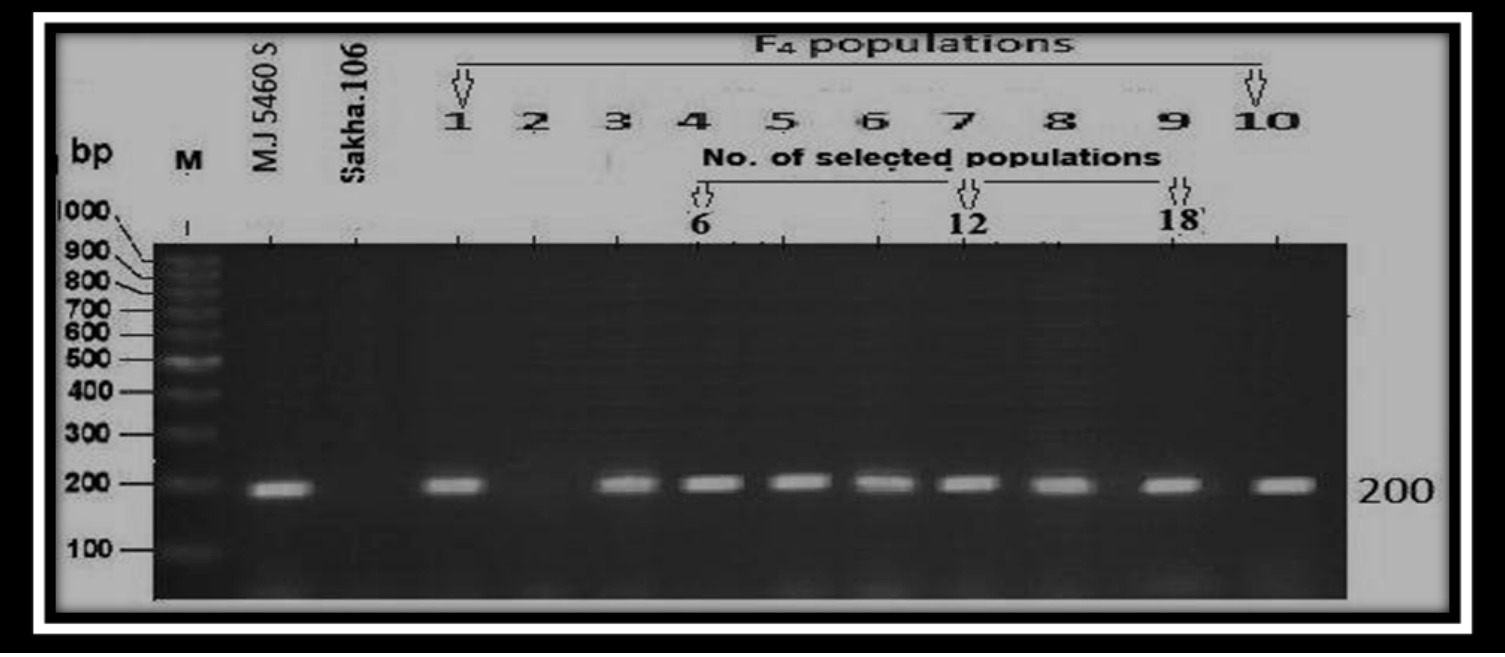

Fig. 1. Agarose gel showing the banding pattern of the tested rice line M.J 5460 S, Sakha 106 and ten selected $F_{4}$ populations using RM222 marker. $M$ is 100 bp DNA ladder.

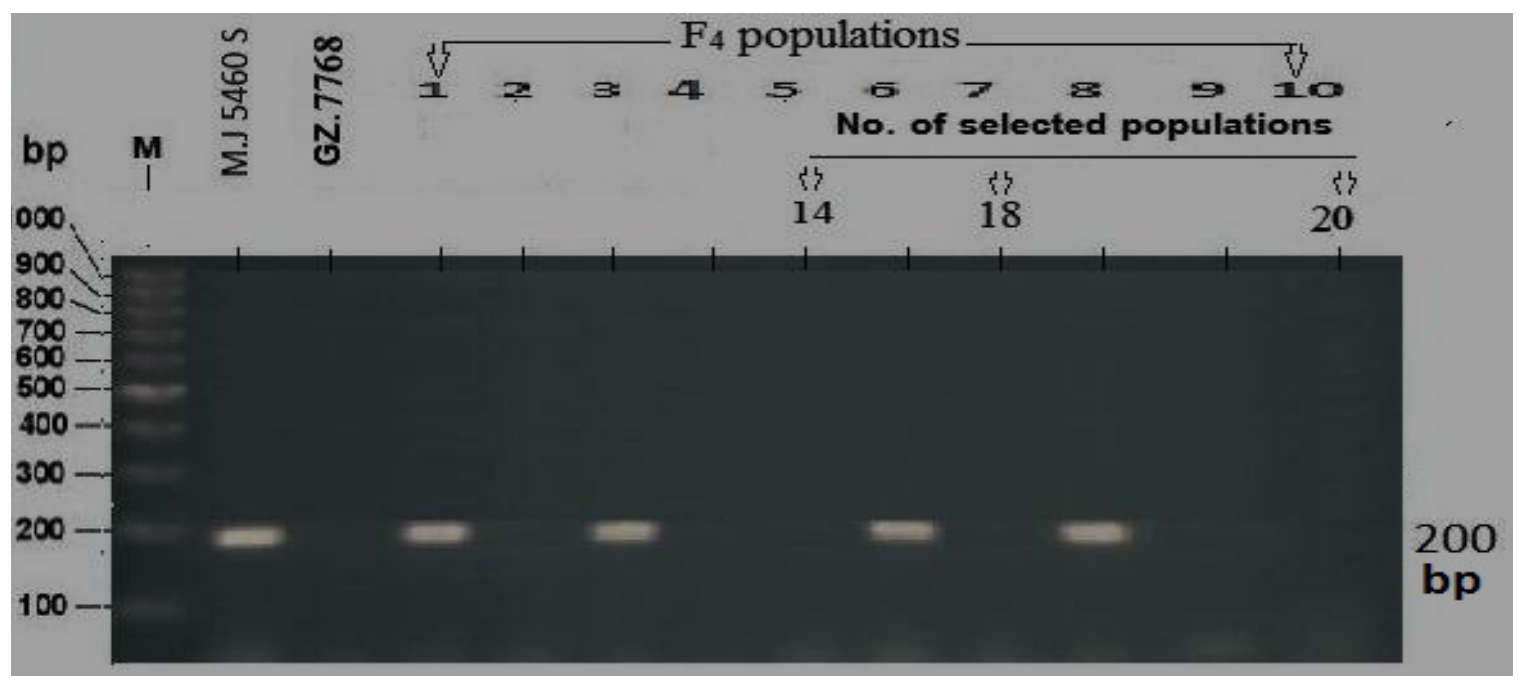

Fig. 2. Agarose gel showing the banding pattern of the tested rice line M.J 5460S, GZ.7768 and ten selected populations of the $F_{4}$ using RM222 marker. $M$ is 100 bp DNA ladder.

J. Sus. Agric. Sci. Vol. 43, No.1 (2017) 


\section{Conclusion}

From the foregoing results, it could be concluded that, the mean performance values indicated the improvement for most studied traits by selection, high heritability in broad sense $\left(h_{2} b\right)$ which indicated that, the genotypic variances played the major part of phenotypic variances for most studied traits. The SSR primer RM222 could be used to identify the rtms gene (s) of rTGMS lines in japonica hybrid rice seed production program. We recommend that, complete selection should be done in late generations on $\mathrm{F}_{4}$ population with numbers 6, 12 and 18 in cross I for release a new stable rTGMS lines which must be used as female lines and $\mathrm{F}_{4}$ populations with numbers 14 , 18 and 20 of cross II which could be used as male lines to produce high yielding Japonica hybrid rice with high productivity under Egyptian condition.

\section{References}

Ahmadikhah, A. (2010) Study on selection effect, genetic advance and genetic parameters in rice. Annals of Biological Research, 1 (4), 45-51.

Allard, R.W. (1964) "Principles of Plant Breeding”. Wiely, N.Y., 458 p.

Comstock, R.E. and Robinson, H.F. (1952) Estimation of average degree of dominance. pp. 494-516. Heterosis. Edited by J.W. Gowen, Iowa Stat. College Press. Amer. Iowa. U.S.A.

Duvick, D.N. (1999) Heterosis: Feeding people and protecting natural resources. In: Genetics and Exploitation of Heterosis in Crops. American Society of Agronomy, Inc., Crop Science Society of America, Inc., Soil Science Society of America, Inc. Madison, Wisconsin, USA.”

El-Shamey, E.A.Z. (2016) Genetical studies on allelopathic activity and yield component in some lines of hybrid rice against barnyardgrass weed under nitrogen stress. Asian J. Plant Sci. Res., 6 (4), 30-36.

Jayashudha, S. and Sharma, D. (2010) Identification of maintainers and restorers for CMS lines of rice under shallow low lands. Electronic Journal of Plant Breeding, 1, 311-314.
Jia, J.H, Zhang, D.S., Li, C.Y., Qu, X.P. and Wang, S.W. (2001) Molecular mapping of the reverse thermo-sensitive genic malesterile gene (rtms1) in rice. Theor. Appl. Genet., 103, 607-612.

Johanson, H.W., Robinson, H.F. and Comstock, R.E. (1955) Estimation of genetic and environmental varation in soybeans. Agron. J., 47, 314-318.

Karuppaiyan, R., Kapoor, C. and Gopi, R. (2013) Variability, heritability and genetic divergence in lowland rice genotypes under the mid-hills of Sikkim. Oryza, 50 (1), 81-84.

Kearsey, M.J. and Pooni, H.S. (1996) "The Genetical Analysis of Quantitative Traits", $1^{\text {st }}$ ed., Chapman and Hall, London, 381 p.

Murray, M.G and Thompson, W.F. (1988) Rapid isolation of high molecular weight plant DNA. Nucleic Acids Research, 8, 43214325.

Parmeshwar, K., Sahu, D.S. Pooja, S.S.S., Chaudhary P.R. and Fakeer C.S. (2015) Assessment of genetic parameters for various quantitative and qualitative traits in hybrid rice (Oryza Sativa L.). International Journal of Tropical Agriculture 33 (1), 97 102.

Patel, A., Chaudhari, P.R. and Verulkar, S.B. (2012) Analysis of genetic variability, heritability and genetic advance for yield and yield components in rice (Oryza sativa L.) under different water regimes. Plant Archives, 12 (1), 425-435.

RRTC Proceeding (2013) Proceeding of the $15^{\text {th }}$ National program work shop (final results of 2013). p.184.

Samadhia, D.K. (2005) Genetic variability studies in Lasora (Cordia myxa Roxb.). Indian J. Plant Genetic Resources, 18 (3), 236-240.

Sedeek, S.E.M., Hammoud, S.A.A., Ammar, M.H. and Metwally, T.F. (2009) Genetic variability, heritability, genetic advance and cluster analysis for some physiological traits and grain yield and its components in 
rice (Oryza Sativa L.). J. Agric. Res. Kafer El-Sheikh Univ. 35 (3), 23-29.

Singh, A.K., Singh, R.K., Kumar, S., Arya, M. and Singh, P.K. (2015) Genetic variability to improve yield and resistance to bacterial leaf blight in rice. Bangladesh J. Bot. 44 (4), 581-589.

Virmani, S.S., Sun, Z.X., Mou, T.M., Juhar, A.A. and Mao C.X. (2003) Tow line hybrid rice breeding manual, pp., 15-22. IRRI, Manila, Philippines.
Yuan, L. P. and Virmani, S. S. (1994) Status of hybrid rice research and development. In: Hybrid Rice, pp., 7-24. IRRI, Manila, Philippines.

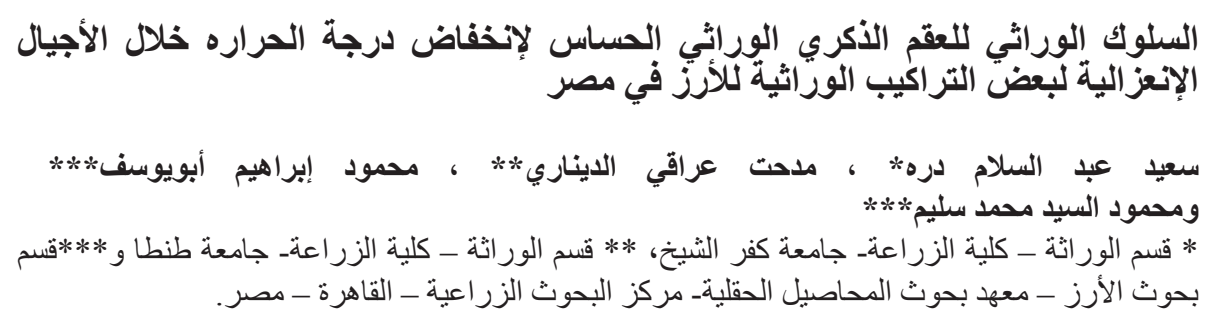

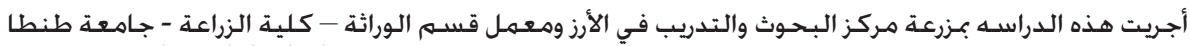

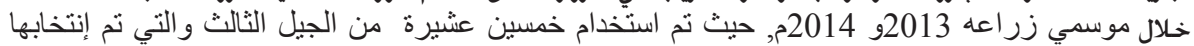

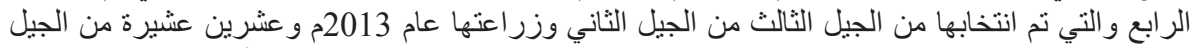
[M.J. 5460 S × Sakha 106 (cross

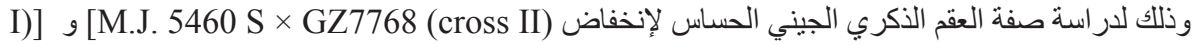
درجة الحرارة, بعض الصفات الخضرية وبعض الصفات الصنة الصحصولية.

كان المتوسط العام لعشائر الجيل الرابع أقل من المتوسط العام لعثائر الجيل الثالث فقط لصفئ عدد الأيام

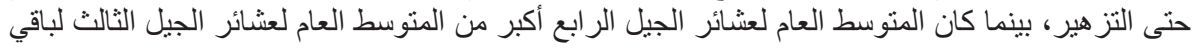

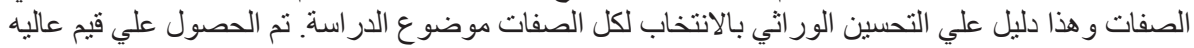

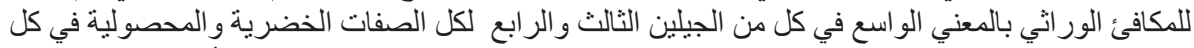

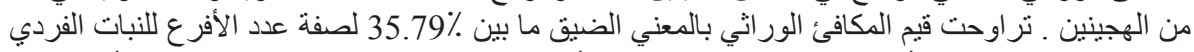

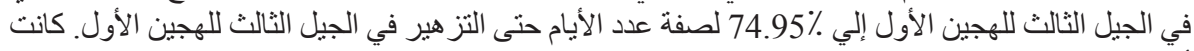

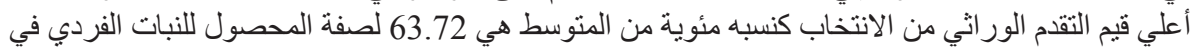
الجيلّ الرابع للاججين الثاني.

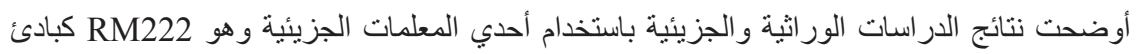

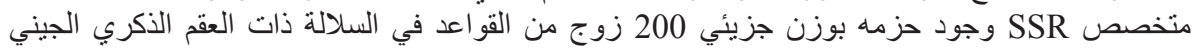

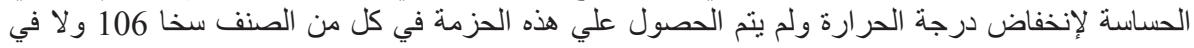

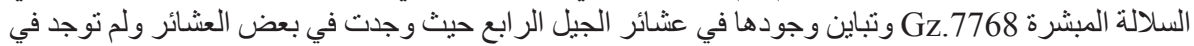

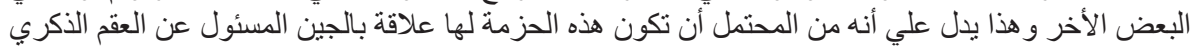

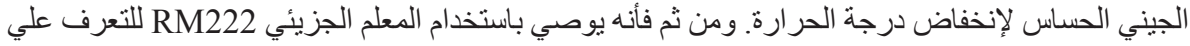

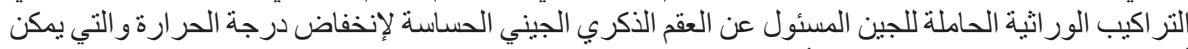
أستخدامها في برامج إنتاج تقاوي الأرز الهجين من الطرأز الياياني الذي يفضله المستهليك المصري. 